\title{
Suppression of the large pine weevil Hylobius abietis (L.) (Coleoptera: Curculionidae) in pine stumps by entomopathogenic nematodes with different foraging strategies
}

\author{
Aoife B. Dillon ${ }^{\mathrm{a}, *}$, Declan Ward ${ }^{\mathrm{b}}$, Martin J. Downes a, Christine T. Griffin ${ }^{\mathrm{a}}$ \\ ${ }^{a}$ Department of Biology and Institute of Bioengineering and Agroecology, NUI Maynooth, Maynooth. Co. Kildare, Ireland \\ ${ }^{\mathrm{b}}$ Coillte Research, Newtown Mountkennedy, Co. Wicklow, Ireland \\ Received 4 October 2005; accepted 8 March 2006 \\ Available online 18 April 2006
}

\begin{abstract}
Hylobius abietis is the most important pest of reforestation in Northern Europe. Weevils develop in stumps of felled conifers and emerging adults feed on and kill young trees. In trials conducted in each of 3 years, entomopathogenic nematodes were applied around pine stumps containing late instar weevils. Since these immature weevils are sedentary and occur within stumps at varying depths in soil, it is predicted that nematodes with a cruise foraging strategy, such as Heterorhabditis spp., should be most effective. The three commercially available species used in our trials, H. megidis, Steinernema feltiae, and $S$. carpocapsae, have cruise, intermediate and ambush strategies, respectively. We also included the indigenous species $H$. downesi and a strain of $S$. feltiae isolated from an Irish coniferous forest. Heterorhabditis downesi suppressed emergence of adult weevils in 2 of 3 trials; and commercial $S$. feltiae and H. megidis NLH85 in 1 trial each. Stump excavation showed that $H$. downesi parasitized 55-63\% of developing weevils; this was matched by H. megidis NLH85 and S. carpocapsae in 2 and 1 years, respectively. A higher proportion of larvae (46\%) than of pupae (32\%) or callow adults $(30 \%)$ were parasitized by nematodes. All nematodes, including $S$. carpocapsae, parasitized weevils $40-49 \mathrm{~cm}$ from the bole of the stump and 30-39 cm below soil level. We conclude that heterorhabditids, particularly $H$. downesi, have greatest potential against pine weevils in stumps, but that a reputation as an ambush forager should not exclude a species such as $S$. carpocapsae from trials against sedentary subterranean insect pests.
\end{abstract}

(C) 2006 Elsevier Inc. All rights reserved.

Keywords: Hylobius abietis; Steinernema feltiae; Steinernema carpocapsae; Heterorhabditis megidis; Heterorhabditis downesi; Entomopathogenic nematodes; Foraging strategy; Cruiser; Ambusher; Biological control agent

\section{Introduction}

The large pine weevil, Hylobius abietis (L.) (Coleoptera: Curculionidae), is the most economically important forest pest in Northern and Eastern Europe (Langstrom and Day, 2004; Leather et al., 1999). It has been estimated that if insecticides were not used, losses in Europe due to the pest would be in the region of 140 million Euros annually (Langstrom and Day, 2004).

\footnotetext{
* Corresponding author. Fax: +35317083845 .

E-mail address: aoife.dillon@nuim.ie (A.B. Dillon).
}

Hylobius abietis breeds in fresh conifer stumps and feeds on young seedlings; hence it is a major pest where clearfelling and replanting is practiced and represents a serious obstacle to successful reforestation (Orlander and Nilsson, 1999). Adult $H$. abietis are attracted to clearfell sites by the volatiles from cut or damaged coniferous trees (Nordlander, 1987; Nordlander et al., 1986). Eggs are laid singly on, or close to, stumps and roots of freshly killed conifers (Eidmann, 1974; Nordenhem and Nordlander, 1994; Norlander et al., 1997). The larvae feed in solitary galleries in or beneath the bark. Under natural conditions the developmental period in the stump from egg to adult is usually between 12 and 36 months, depending on temperature (Leather et al., 1999). Adult weevils feeding on the seedling 
stem from the root collar upwards cause the damage. This may result in complete girdling, causing plant death. While the majority of feeding damage occurs during the first year after planting, seedlings have been reported to be susceptible to weevil damage for up to 5 years (Orlander et al., 1997; Selander, 1993).

Chemical protection of conifer seedlings is the main control measure currently employed in most countries which practice reforestation (Langstrom and Day, 2004). In Ireland and Britain, $H$. abietis is the only forest insect pest against which routine chemical control measures are applied (Ward et al., 1993; Willoughby et al., 2004). Seedlings on reforestation sites are routinely treated with $\alpha$-cypermethrin pre- and post-planting. As a participant of the sustainable forest management (SFM) agreement, the European Union has agreed to reduce chemical usage and increase biodiversity when developing forestry. Alternative approaches for mitigating the effects of $H$. abietis (reviewed by Langstrom and Day, 2004) include physical protection of seedlings using collars and waxes, an approach that has received much attention in Sweden, and sylvicultural measures such as the provision of shelter trees and alternative food. Of the possible biological control agents that might be deployed against $H$. abietis, entomopathogenic nematodes are the most promising (Kenis et al., 2004).

Entomopathogenic nematodes (EPNs) of the families Steinernematidae and Heterorhabditidae (Nematoda: Rhabditida) are lethal pathogens of insects. Their pathogenicity is partly due to their symbiotic association with bacteria of the genera Xenorhabdus and Photorhabdus, respectively (Forst et al., 1997). Non-feeding infective juveniles (IJs) actively seek out insects in soil and other cryptic media. They enter the insect through the natural openings and, in the case of Heterorhabditis, through the cuticle. In the insect hemocoel, the IJs release their symbiotic bacteria from their gut. Death of the insect ensues, often within $48 \mathrm{~h}$. The nematodes reproduce in the insect cadaver, producing fresh IJs, which emerge from the depleted cadaver 2-3 weeks after infection. A single cadaver can yield tens or even hundreds of thousands of IJs. More than 40 species of EPN, mainly Steinernema spp., have been described. Some species are globally distributed within a broad climatic zone, while others are known from a more restricted geographic region (Hominick, 2002). Several species of EPN are produced in bioreactors and are traded globally, mainly for inundative application against soil-dwelling stages of pest species (Grewal et al., 2005; Shapiro-Ilan et al., 2002).

All stages of $H$. abietis are susceptible to entomopathogenic nematodes (Brixey, 1997, 2000; Collins, 1993; Pye and Burman, 1978). Early field experiments in Sweden targeted adults; seedlings dipped in a suspension of Steinernema carpocapsae (Weiser) significantly reduced feeding damage compared to control seedlings (Pye and Pye, 1985). Similarly, conifer seedlings were protected against the North American species Hylobius congener (Dalla torre Schenkling and Marshall) by treating the roots with $S$. carpocapsae before planting (Eidt et al., 1995). However, field trials in Britain using nematodes on containerized and bare root planting stock did not produce a significant reduction in $H$. abietis adult feeding damage to the plants (Brixey, 1997). The alternative strategy in using nematodes against pine weevil is to target the developmental stages within the stumps, with the aim of suppressing the population of adult weevils emerging on a site. Following the success of preliminary Swedish field trials using S. carpocapsae (Burman et al., 1979), extensive research has been undertaken by the UK Forestry Commission in Scotland. Timing of application was found to be one of the most important factors affecting efficacy, with applications against late instar larvae and pupae more successful than against early instars (Brixey, 1997). S. carpocapsae was reported to be more reliable than S. feltiae (Filipjev) or Heterorhabditis megidis (Poinar, Jackson, and Klein) (Brixey, 1997). The success of subsequent extended field trials and semi-operational use of S. carpocapsae has led to the conclusion that entomopathogenic nematodes are a useful component of an integrated management program for $H$. abietis (Evans et al., 2004).

The success of $S$. carpocapsae against immature $H$. abietis would not be predicted based on background knowledge of the biology of this nematode. Similarly unexpected is the relative performance of three species in a trial in lodgepole pine. S. carpocapsae and S. feltiae each killed over $50 \%$ of immature weevil in the stumps, compared to $37 \%$ for $H$. megidis (Brixey, 2000); however, the differences were not significant and results were based on a single trial. Species of entomopathogenic nematode are reported to display differing foraging strategies, on a continuum from extreme ambush foragers to extreme cruisers (Campbell and Gaugler, 1997; Grewal et al., 1994; Lewis et al., 1992). S. carpocapsae is described as a classic ambush forager, remaining near the soil surface and attaching to mobile hosts; Heterorhabditis spp. are classified as cruise foragers, ranging widely and responding to volatiles from sedentary hosts, and $S$. feltiae is described as having an intermediate foraging strategy (Campbell and Gaugler, 1997; Grewal et al., 1994). Ambushers are expected to be more successful against mobile insects on the soil surface and cruisers for sedentary and/or subterranean hosts (Campbell and Gaugler, 1993; Koppenhöfer and Kaya, 1996). Thus, the cruise foraging Heterorhabditis spp. are expected to perform better against immature pine weevils in tree stumps than $S$. feltiae with its intermediate strategy, and the ambush forager S. carpocapsae is expected to be the least suitable species for this task.

The main aim of the present study was to compare the performance of a number of entomopathogenic nematode species against immature stages of $H$. abietis developing in pine stumps. Nematodes were chosen so as to include species exhibiting diverse foraging strategies and to include both exotic and indigenous species. Trials included commercial formulations of the three species tested by Brixey (2000): S. carpocapsae, S. feltiae, and H. megidis. We also included Irish isolates of two of the three species that have been identified in this country: H. downesi (Stock, Burnell and Griffin) and $S$. feltiae. The third indigenous species, 
S. affine (Bovien) (Griffin et al., 1991) was rejected based on poor performance against pine weevil larvae in laboratory bioassay (Dillon, 2003). While the use of non-indigenous nematode species is not prohibited in Ireland, a native species would be more desirable for environmental reasons, if it was found to be equally practical and effective.

\section{Materials and methods}

\subsection{Experimental sites}

Field trials (1 per year) were conducted in 2001, 2002, and 2003. The 2001 and 2002 trials were carried out in Ballyroan Forest in Co. Laois in central Ireland $\left(\mathrm{N}=53^{\circ} 22^{\prime}\right.$, $\mathrm{W}=006^{\circ} 07^{\prime}$; elevation $\left.4 \mathrm{~m}\right)$. The stumps in these sites were $70 \%$ lodgepole pine (Pinus contorta Dougl. ex Loud) and $30 \%$ Scots pine (Pinus sylvestris L.) on a deep peat soil. The 2003 site was approximately $20 \mathrm{~km}$ north, in Ballybrittas Forest, Co. Laois; stumps were of Scots pine, on a shallow peat soil. In each trial, stumps were from trees felled 18 months prior to the test. Trees were felled in December 1999, 2000, and 2001, and nematodes were applied in the second week of June in 2001, 2002, and 2003, respectively.

\subsection{Nematodes}

Commercially produced nematodes were supplied on an inert carrier in a wettable powder formulation. S. carpocapsae All strain $\left(\right.$ Carponem $\left.{ }^{\mathrm{R}}\right)$ was supplied by Koppert, Berkel en Rodenrijs, Holland. S. feltiae EN02 (Nemaplus ${ }^{\mathrm{R}}$ ) was supplied by E-Nema GmbH, Raisdorf, Germany. H. megidis UK211 (Nemasys- $\mathrm{H}^{\mathrm{R}}$ ) was supplied in 2001 by BeckerUnderwod, UK; however, production of this nematode was then discontinued. In 2002 and 2003 Koppert, Suffolk, UK supplied H. megidis NL-HF85 (Larvanem-Hm ${ }^{\mathrm{R}}$ ). S. feltiae 4CFMO and $H$. downesi K122 were from our own collection at NUIM in Ireland. Commercially produced nematodes were obtained from the supplier less than a week before use and stored at $9^{\circ} \mathrm{C}$ until required. The product was mixed with water to the desired concentration of nematodes. In vivo nematode production was in late instar larvae of the wax moth Galleria mellonella (L.) at $20^{\circ} \mathrm{C}$ (Woodring and Kaya, 1988). Cadavers containing nematodes were placed in White traps to harvest the emerging IJs. IJs were harvested daily for 3 days from the time of first emergence and harvests were pooled. Harvested IJs were washed by sedimentation in three changes of tap water. They were stored for up to a week at $9{ }^{\circ} \mathrm{C}$ in $50 \mathrm{ml}$ aliquots $(5000 \mathrm{IJs} / \mathrm{ml})$ in $9 \mathrm{~cm}$ diam. food containers with snap-on lids. Nematodes were transported to the field site in 5-liter bottles, which were continuously shaken to aerate the suspension.

\subsection{Application of entomopathogenic nematodes to pine stumps}

A suspension of 3.5 million IJs in $500 \mathrm{ml}$ of tap water was applied around each stump. Control stumps received
$500 \mathrm{ml}$ of tap water. The dry needle litter was removed and the nematode suspension was poured onto the soil around the stump in a band approximately $5 \mathrm{~cm}$ wide. The litter was then replaced to protect the nematodes against ultraviolet radiation and desiccation. Only stumps with a diameter greater than $25 \mathrm{~cm}$ were used. No distinction was made between the two pine species on mixed sites.

In each of the three trials, a water control and at least five nematode treatments were tested. The five nematode treatments included in each trial were three commercially produced strains (S. carpocapsae All strain, S. feltiae EN02 and $H$. megidis UK211 or NL-HF85) and two in vivo-produced Irish strains ( $S$. feltiae $4 \mathrm{CFMO}$ and $H$. downesi K122). In 2002, there were three additional nematode treatments. These were each of the three commercial nematode strains produced in vivo using wax moth larvae (as described above).

The experiments were set out in a randomized block design, with 1 stump of each treatment per block. In 2001, 26 blocks were treated: 7 for emergence traps and 19 for destructive sampling. In 2002, 20 blocks were treated, 10 for emergence traps and 10 for destructive sampling. For two of the nematode treatments (H. downesi and in vivo-produced $S$. carpocapsae), there were two stumps per block, for destructive sampling after 2 and 4 weeks, respectively. In 2003, 17 blocks were treated: 7 for emergence traps and 10 for destructive sampling.

\subsection{Assessment of parasitism of H. abietis in stumps}

Stumps were normally sampled 4 weeks after nematode application. A quarter of each stump was destructively sampled and the number of infected and uninfected weevil larvae, pupae and immature adults in that quarter was counted. First, the brash and soil were cleared from a quarter of the stump and associated roots. The bark was removed using a chisel and broken apart to reveal any insects that were inside. Pupal chambers in the timber were excavated with the chisel. Roots were stripped to a distance of $40 \mathrm{~cm}$ in 2001 and $50 \mathrm{~cm}$ in 2002 and 2003 . To examine the bole/root junction and the under-surface of the root, the roots were cut from the trunk using a chainsaw. Insects parasitized by nematodes were recognized by characteristic color changes. The developmental stage, status and location of each $H$. abietis were recorded. The location was recorded as both vertical distance from the soil surface (depth) and the horizontal distance from the bole of the stump. In 2002, insects were brought back to the lab and stored at $20^{\circ} \mathrm{C}$ for $4-5$ days and any further mortality was recorded.

\subsection{Use of insect emergence traps to assess the efficiency of entomopathogenic nematodes against Hylobius abietis in stumps}

Stumps that were not destructively sampled were covered with baited insect traps designed to catch emerging 
adults. Traps were based on the design of Moore (2001), without the electric shock device. A pyramid of black cotton overlaying a bamboo tripod covered each stump. The traps were $1 \mathrm{~m}$ high and covered an area of ground of approx. $0.4 \mathrm{~m}^{2}$. To prevent adult weevils exiting under the trap, and to hold the trap in position, excess material at the base of the pyramid was spread out on the soil surface to a distance of $50 \mathrm{~cm}$ and covered with soil to a depth of 5$10 \mathrm{~cm}$. A clear plastic cylinder for collecting weevils was at the apex of the tripod and provided the only source of light entering the trap.

The collecting cylinder was made from 2-liter clear plastic drinks bottles. Bottles were cut and taped to create a cylinder $32 \mathrm{~cm}$ in length and $10 \mathrm{~cm}$ in diameter, closed at the top and bottom. The cylinder consisted of an upper chamber leading into a lower collecting chamber through an internal funnel. It was held in place by inserting the three bamboo stakes through three equidistant holes (diam. $2 \mathrm{~cm}$ ) $7 \mathrm{~cm}$ from the top (in the upper chamber). The trap material was taped to the cylinder above these structural holes so that weevils could not escape. Six smaller holes (diam. $1.5 \mathrm{~cm}$ ) just below the structural holes allowed insects to enter the upper chamber of the collecting cylinder. Insects climbing up the material of the trap were encouraged to enter the cylinder using an olfactory lure (Nordlander, 1987). Two 50-ml centrifuge tubes, containing $30 \mathrm{ml}$ of turpentine and $30 \mathrm{ml}$ of $70 \%$ ethanol, respectively, were suspended from the top of the cylinder. A slit in the lid of each tube allowed the slow release of odors. Insects entering the upper chamber fell through the funnel and were collected in the lower chamber.

In 2001 and 2002, emergence insect traps were erected 7 weeks after nematode application and checked 9, 11, 13, 15, 17 , and 19 weeks after nematode application. In 2003 they were erected 9 weeks and checked 11,13, and 17 weeks after nematode application. At each assessment date, trapped insects were removed and counted.

\subsection{Statistical analysis}

Routine statistics were performed using MINITAB Release 13 for Windows (Minitab Inc., 2000). Significance levels were taken at $P<0.05$. Data were tested for normality using the Anderson Darling test and, where found to be non-normal data, were transformed. Emergence data were transformed using a square root transformation. Percentage parasitism data were transformed using arcsine square root transformations. More than two treatments were compared using General Linear Model ANOVA, followed by pairwise comparisons (Tukey's test; $\alpha=0.05$ ). Percentage parasitism data were based on mortality at the time of collection in every instance, except when investigating the effect of assessment time (2 versus 4 weeks) on nematode parasitism of weevils in stumps, where analysis was performed on mortality values recorded following incubated for a further $4-5$ days at $20^{\circ} \mathrm{C}$. As all developmental stages were not present in all years, average values from each year were used to analyze percentage parasitism in relation to developmental stage. The percentage of insects at each depth and distance in control stumps were compared using ANOVA where data were normal, and Friedman where there were severe departures from normality (many zero values). Regression analysis on percentage parasitism at each depth and distance was performed using the average values obtained in each year. Regression lines (residual variances, slope, and elevation) were compared using Statistix ${ }^{\circledR} 8$ (Analytical Software, USA, 2005). The average number of live insects in the stumps was correlated with the average number of adults captured in the traps using Pearson's correlation.

\section{Results}

\subsection{Reduction of adult emergence by entomopathogenic nematodes}

Application of nematodes reduced the number of $H$. abietis adults emerging from stumps by up to $87 \%$ compared to controls (Fig. 1). Both year and treatment affected the number of adults emerging $(F=38.06 ; d f=2$, $126 ; P<0.001$ and $F=14.34 ; d f=5,126 ; P<0.001$, respectively), and there was an interaction between these factors $(F=2.84 ; d f=10,126 ; P<0.01)$. In 2001 , the average number of adults emerging from a stump was lower in stumps treated with $H$. downesi ( $87 \%$ reduction) and the commercial preparation of $S$. feltiae EN02 (61\% reduction) than in the controls (141 insects per stump) (Fig. 1). In 2002, fewer adults emerged from stumps treated with $H$. downesi $(87 \%$ reduction) or H. megidis $(70 \%$ reduction), compared to the control stumps ( 84 insects per stump) (Tukey's). The overall lower number of insects emerging in 2003 (37 insects/control stump) probably accounts for the failure to detect significance between the treatments in that year. Application of $S$. carpocapsae All strain and the indigenous $S$. feltiae 4CFMO to stumps failed to reduce adult emergence compared to the controls in each of the 3 years (Tukey's).

\subsection{Parasitism by nematodes of weevils in stumps}

In the control treatments, no weevils were parasitized by nematodes in any of the three trials. A low level (3.1-7.1\%) of natural weevil mortality was recorded, including some due to the larval parasitoid Bracon hylobii (Ratz.).

All of the nematodes tested parasitized H. abietis in the stumps (Fig. 2). The percentage of insects parasitized varied with nematode treatment $(F=20.54 ; d f=4,176 ; P<0.001)$, but not with year $(F=1.03 ; d f=2,176 ; P>0.05)$. There was, however, an interaction between nematode treatment and year $(F=8.82 ; d f=8,176 ; P<0.001)$. The highest level of parasitism was in stumps treated with $H$. downesi $\mathrm{K} 122$ (63, 60, and 55\% in 2001, 2002, and 2003, respectively) 


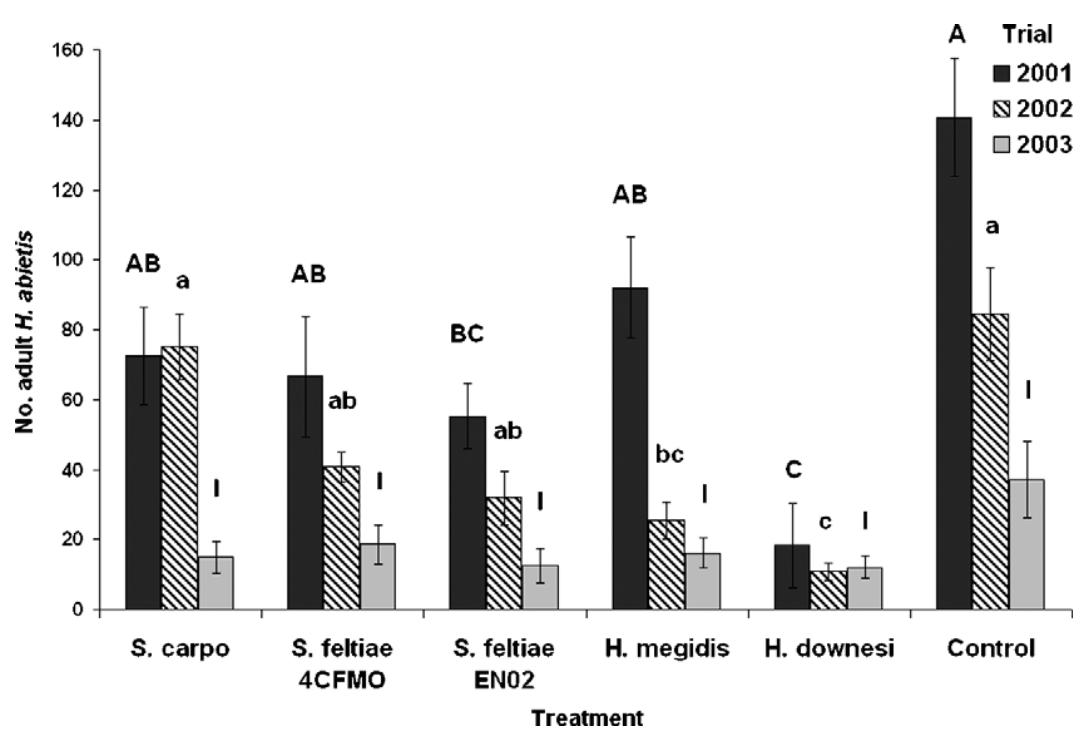

Fig. 1. Number (means \pm SE) of H. abietis adults emerging from pine stumps. Emergence was recorded over a period of 12 weeks in 2001 and 2002 (7-19 weeks after nematode application) and over 8 weeks in 2003 (9-17 weeks after nematode application). Within a trial, different letters (uppercase in 2001 and lowercase in 2002) or Roman numerals (2003) above a column indicate significant differences between treatments (Tukey's at $P=0.05$, following ANOVA, $P<0.05$ ). S. carpo = Steinernema carpocapsae. The strain of H. megidis was UK211 in 2001 and NL-HF85 in 2002 and $2003 . n=7$ stumps in 2001 and $n=10$ stumps in 2002 and 2003.

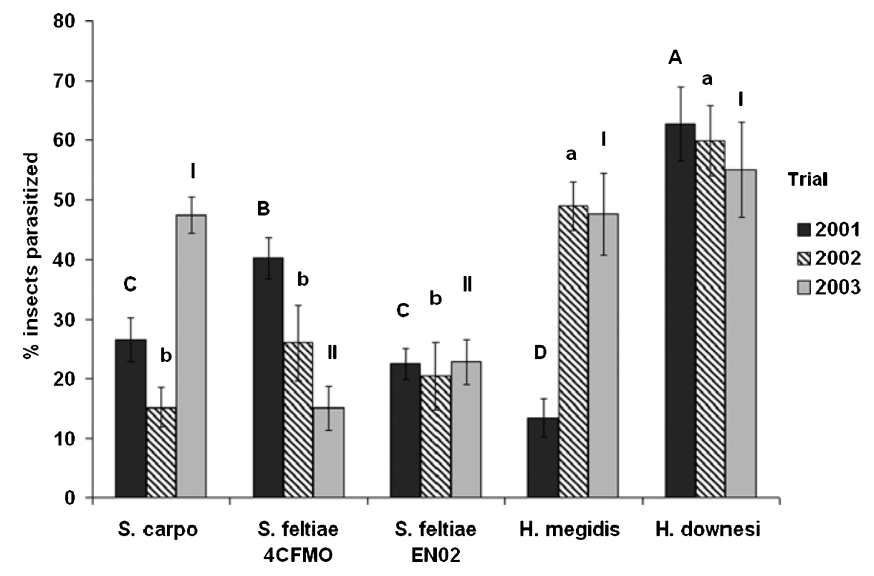

Fig. 2. Percentage (means $\pm \mathrm{SE}$ ) of $H$. abietis parasitized by entomopathogenic nematodes (Steinernema spp. and Heterorhabditis spp.) in each of three trials, 1 per year. In each trial, pine quarter stumps were destructively sampled 4 weeks after application of nematodes. Within a trial, different letters (uppercase in 2001 and lowercase in 2002) or Roman numerals (2003) above a column indicate significant differences between treatments (Tukey's at $P=0.05$, following ANOVA, $P<0.05$ ). $S$. carpo $=$ Steinernema carpocapsae. The strain of H. megidis was UK211 in 2001 and NL-HF85 in 2002 and 2003. $n=19$ stumps in 2001 and $n=10$ stumps in 2002 and 2003.

(Fig. 2). The lowest parasitism rate recorded in 2001 was in stumps treated with $H$. megidis UK211 (13\%). However, in 2002 and 2003 the percentage of insects parasitized by $H$. megidis NL-HF85 (49 and 48\%, respectively) was similar to that of $H$. downesi in those years. Parasitism by S. carpocapsae All strain ranged from $15 \%$ of insects in 2002 to $47 \%$ in 2003. Parasitism by the indigenous $S$. feltiae 4 CFMO ranged from $15 \%$ in 2003 to $40 \%$ in 2001 . A relatively low level of parasitism (20-23\%) was consistently recorded in stumps treated with the commercial preparation of $S$. feltiae EN02.

\subsection{Effect of assessment time on nematode parasitism of weevils in stumps (2002)}

In 2002, stumps treated with two nematode species were assessed 2 and 4 weeks after nematode application. Since we were interested in knowing how quickly the nematodes had reached and invaded the weevils, insects collected in the field were incubated for a further 4-5 days before the final mortality was recorded. Insects continued to die following their removal from the field, especially in the 2-week assessment when there was a $45 \%$ increase in mortality due to $H$. downesi and a $65 \%$ increase in S. carpocapsae-induced mortality, while insects collected after 4 weeks showed a negligible increase in mortality on further incubation (Fig. 3).

The percentage of insects parasitized after incubation was influenced both by nematode species and by the time between nematode application and stump assessment ( 2 or 4 weeks $)$ and $(F=8.57 ; d f=1,36 ; P<0.01$ and $F=14.42$; $d f=1,36 ; P=0.001$, respectively), with no interaction between the two factors $(F=0.00 ; d f=1,36 ; P>0.05)$. The percentage of insects killed by $H$. downesi increased from $40 \%$ in stumps that were sampled after 2 weeks to $60 \%$ when sampled after 4 weeks (Tukey's). The percentage of insects killed by $S$. carpocapsae was $24 \%$ after 2 weeks and $45 \%$ after 4 weeks (Tukey's) (Fig. 3).

\subsection{Effect of nematode rearing method on parasitism rate (2002)}

When commercially formulated nematodes were compared to the same isolates reared in vivo, the percentage of insects parasitized was influenced by nematode species $(F=5.75 ; d f=2,51 ; P<0.01)$ and rearing method $(F=9.70$; $d f=1,51 ; P<0.01)$. There was also an interaction between 


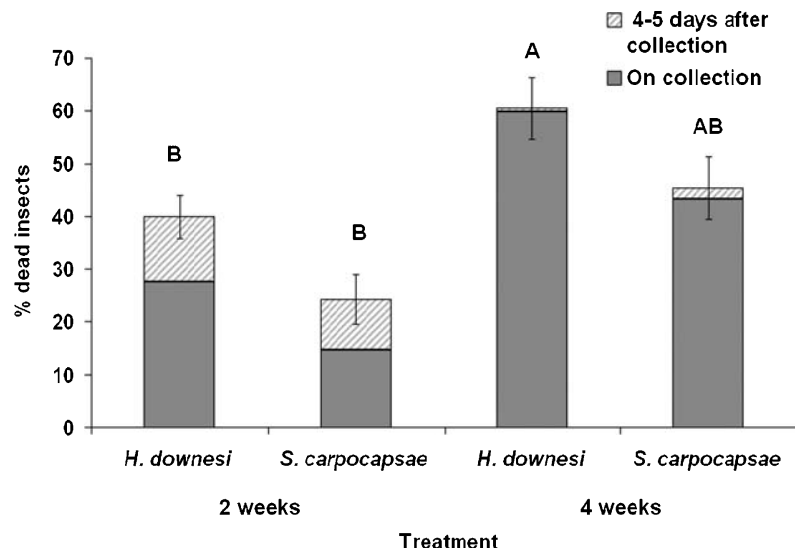

Fig. 3. Percentage (means \pm SE) of $H$. abietis parasitized by entomopathogenic nematodes in stumps that were destructively sampled 2 or 4 weeks after application of $H$. downesi and S. carpocapsae in $2002 \quad(n=10$ stumps). Parasitism was recorded at the time of stump destruction and again after the field-collected insects had been incubated for 4-5 days at $20^{\circ} \mathrm{C}$. Different letters above a column indicate significant differences between treatments when assessed following incubation (Tukey's at $P=0.05$, following ANOVA, $P<0.05$ ).

species and rearing method $(F=8.26 ; d f=2,51 ; P=0.001)$. For $S$. carpocapsae and $S$. feltiae EN02, the percentage of insects parasitized by in vivo produced nematodes was higher than for the commercial product (Tukey's), while production method did not affect the percentage of insects parasitized by H. megidis (Fig. 4).

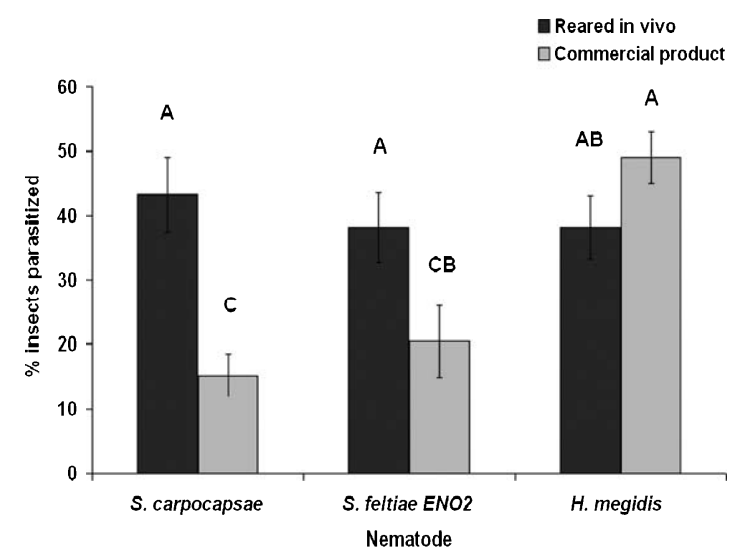

Fig. 4. Percentage (means $\pm \mathrm{SE}$ ) of $H$. abietis parasitized by entomopathogenic nematodes that had either been produced commercially in vitro or were reared in vivo in wax moth larvae in the 2002 trial ( $n=10$ stumps). Pine quarter stumps were destructively sampled 4 weeks after application of nematodes. Different letters above a column indicate significant differences between treatments (Tukey's at $P=0.05$, following ANOVA, $P<0.05)$.

\subsection{Population structure in the control stumps, and parasitism in relation to weevil developmental stage}

When control stumps were sampled 4 weeks after nematode application (19 months after felling), the majority of the insects (58-71\%) were at the pupal stage (Table 1). Larvae were all late instar. Adults were present in 2001 and 2002, and a small number of adults had already emerged in 2001 .

In the nematode treatments, percentage parasitism was influenced by weevil developmental stage $(F=5.30 ; d f=2$, $26 ; P<0.05)$ and by nematode treatment $(F=8.15 ; d f=4$, $26 ; P<0.001)$, with no interaction between these two factors $(F=0.59 ; d f=8,26 ; P>0.05)$. A higher proportion of larvae $(45 \%$ overall) than of either pupae $(32 \%)$ or adults (30\%) were parasitized (Fig. 5).

\subsection{Location of immature H. abietis in control stumps and parasitism in relation to horizontal distance and depth}

More than half $(55 \%)$ of $H$. abietis in the control quarter-stumps were recovered less than $10 \mathrm{~cm}$ from the bole (Fig. 6A). The probability of recovering immature $H$. abietis was strongly influenced by distance from the bole in each year (2001: $F=14.35 ; d f=3,72 ; P<0.001 ; 2002$ : $F=9.54 ; d f=4,39 ; P<0.001$ and 2003: $S=21.20 ; d f=4$; $P<0.001)$.

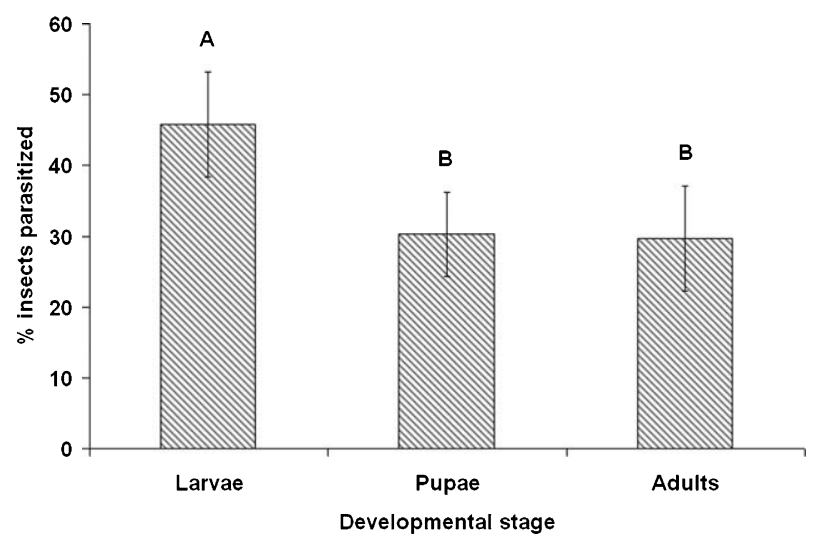

Fig. 5. Percentage (means \pm SE) of each developmental stage of H. abietis parasitized by entomopathogenic nematodes. Pine stumps were destructively sampled 4 weeks after application of 3.5 million nematode infective juveniles per stump. Data are based on average across 3 years. Different letters above a column indicate significant differences between treatments (Tukey's at $P=0.05$, following ANOVA, $P<0.05)$.

Table 1

Population structure of H. abietis (as a percentage of the total number of insects found) in pine quarter stumps in July of each of three years

\begin{tabular}{llllllll}
\hline Year & Larvae (\%) & Pupae $(\%)$ & Adults $(\%)$ & Empty chambers $(\%)$ & Total no. of insects $(n)$ & Range (insects per quarter-stump) & No. of stumps \\
\hline 2001 & $11.6 \mathrm{a}$ & $57.7 \mathrm{a}$ & $29.6 \mathrm{a}$ & $1.1 \mathrm{a}$ & 449 & $0-60$ & 19 \\
2002 & $28.9 \mathrm{a}$ & $71.1 \mathrm{a}$ & $0.0 \mathrm{~b}$ & $0.0 \mathrm{a}$ & 315 & $0-70$ & 10 \\
2003 & $21.4 \mathrm{a}$ & $66.1 \mathrm{a}$ & $12.5 \mathrm{ab}$ & $0.0 \mathrm{a}$ & 168 & $0-46$ & 10 \\
\hline
\end{tabular}

In each case, trees had been felled 19 months previously. Data are for control stumps that did not receive nematodes. Within column values that share a letter are not significantly different at $P<0.05$ (ANOVA, Tukey). 

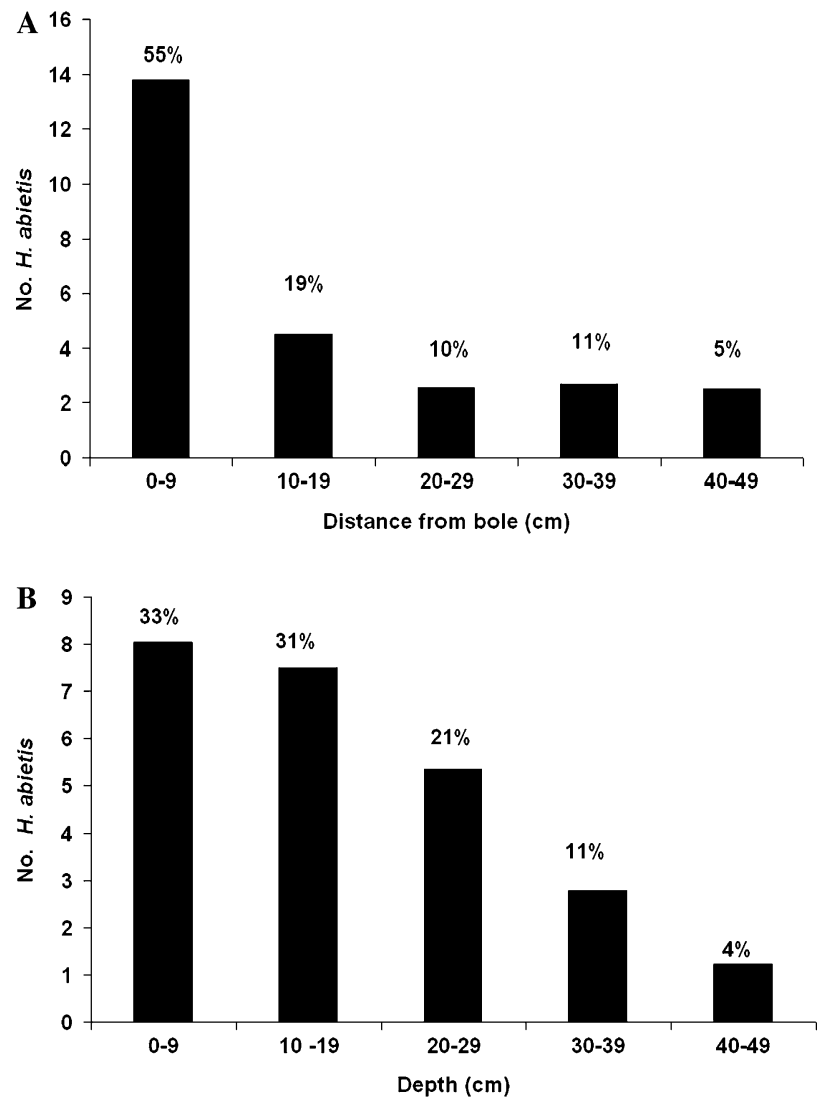

Fig. 6. The horizontal (A) and vertical (B) distribution of immature $H$. abietis in pine quarter stumps destructively sampled 19 months after felling. Bars show the mean number of insects per stump at varying distances from the bole, and the figure above the bar gives this as a percentage of the weevils recovered. Data are for control stumps from all 3 years combined ( $n=39$ stumps).

Over $60 \%$ of weevils were found in the upper $20 \mathrm{~cm}$ of soil (Fig. 6B). The probability of finding weevils declined with increasing depth, but the decline was less steep than for horizontal distance. Depth influenced the probability of locating $H$. abietis in the control quarter-stumps in 2001 and $2003(S=11.38 ; d f=3 ; P<0.01$ and $S=19.54 ; d f=4$; $P<0.001)$ but not in $2002(F=2.03 ; d f=4,45 ; P>0.05)$.

Both distance from the bole and depth below soil level influenced the percentage of insects parasitized. The percentage of insects parasitized decreased with horizontal distance from the bole for each of the nematode treatments, dropping from $31-79 \%$ of insects within $9 \mathrm{~cm}$ of the bole, to $4-21 \%$ of insects at $40-49 \mathrm{~cm}$ (Fig. 7). The regression lines for the five treatments were compared. Homogeneity of residual variances was confirmed using Bartlett's test of equal variance $\left(\chi^{2}=5.62 ; d f=4 ; P>0.05\right)$. There were significant differences between the lines for the five nematode treatments in both slope and elevation $(F=4.76 ; d f=4,15 ; P<0.05$ and $F=22.49 ; d f=4,15 ; P<0.001$, respectively), but when $H$. downesi (steep sloped) was omitted, the slope of the other four did not differ significantly $(F=0.48 ; d f=3,12 ; P>0.05)$.

The percentage of insects parasitized decreased with depth for each of the nematode treatments (Fig. 8), dropping from $41-81 \%$ within $9 \mathrm{~cm}$ of the soil surface, to $1-32 \%$

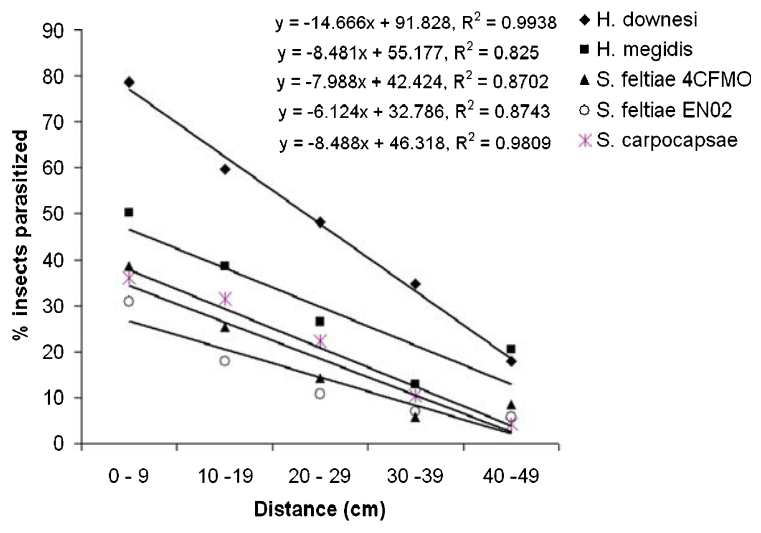

Fig. 7. Effect of horizontal distance from the bole of the stump on the percentage of $H$. abietis parasitized by various species and strains of entomopathogenic nematodes. Data are based on average across 3 years.

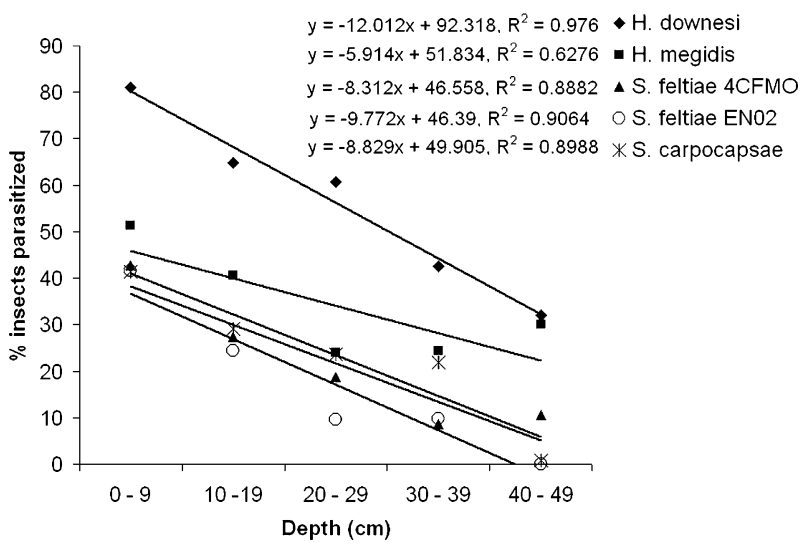

Fig. 8. Effect of depth below soil level on the percentage of Hylobius abietis parasitized by various species and strains of entomopathogenic nematodes. Data are based on average across 3 years.

at a depth of between 40 and $49 \mathrm{~cm}$. The nematodes with the steepest and most shallow gradient were $H$. downesi and $H$. megidis, respectively. The regression lines for the five treatments were compared. Homogeneity of residual variances was confirmed (Bartlett's test of equal variance, $\left.\chi^{2}=1.98 ; d f=4 ; P>0.05\right)$. There were significant differences for elevation $(F=32.85 ; d f=4,19 ; P<0.001)$, but not for slope $(F=1.45 ; d f=4,15 ; P>0.05)$.

\subsection{Efficiency of emergence traps and comparison of adult emergence and stump destruction}

Using the data for all of the treatments, there was a correlation between the number of live insects found in destructively sampled stumps and the number of adult weevils captured in the traps in 2001 (Pearson's correlation on $\log$ transformed data $0.863, P=0.027)$, and $2002(0.945$, $P=0.004)$ but not in $2003(0.119, P=0.822)$.

\section{Discussion}

The most important measure of the success of a stump treatment for pine weevil suppression is the extent to which 
it reduces the number of adult weevils emerging from treated stumps relative to control stumps. On this basis, the indigenous $H$. downesi performed best. In both 2001 and 2002, the number of adult weevils from $H$. downesi-treated stumps differed significantly from all but one other nematode treatment (a different nematode in each year). H. downesi reduced emergence of adults by between 68 and $87 \%$ over the 3 years. The efficacy of $H$. megidis is more difficult to assess, as each of the two strains was tested in only one or two trials: H. megidis NL-HF85 reduced weevils by 70 and $57 \%$ in 2002 and 2003, respectively. On the other hand, H. megidis UK211 reduced adult weevils by only $35 \%$ in 2001 , the worst performance in that trial. The poor performance of UK211 relative to other treatments in suppressing adult emergence was supported by a low percentage parasitism in the destructive stump sampling. As in our 2001 trial, and using similar methods, Brixey (2000) found that a commercial preparation of $H$. megidis UK211 parasitized fewer pine weevils than commercial preparations of either $S$. feltiae or $S$. carpocapsae, and the lower infection rate in that trial "approached significance $(P<0.1)$." The UK211 strain may not be as suitable for pine weevil suppression as either $H$. megidis NL-HF85 or $H$. downesi K122.

Based on the foraging strategy of these species - heterorhabditids are described as cruise foragers (Campbell and Gaugler, 1997; Grewal et al., 1994) - it is not unexpected that $H$. downesi and $H$. megidis NLHF85 performed well against immature pine weevils developing below ground. However, the variation in the performance of $H$. megidis strains shows that this is not always the case for all heterorhabditids.

It was predicted that $S$. carpocapsae should not perform well based on its ambush foraging strategy. The performance of this species was highly variable from year to year, ranging from $11 \%$ reduction of adults in 2002 to $60 \%$ reduction in 2003. This variability in efficacy of $S$. carpocapsae is also seen in the results of destructive stump sampling. In 2003, the percentage of insect parasitized by commercially produced $S$. carpocapsae did not differ from H. downesi. S. carpocapsae produced in vivo in 2002 also did not differ from $H$. downesi in that trial, although the commercial product used in the same trial parasitized fewer insects.

The fact that the indigenous Irish species $H$. downesi performed best is gratifying, since use of exotic species is less desirable for environmental reasons (Ehlers and Hokkanen, 1996). H. downesi also occurs in Britain and continental Europe (Stock et al., 2002), and so could be used more widely. The other indigenous strain tested, S. feltiae 4CFMO, was not particularly successful. It was originally isolated from soil in a clearfell coniferous forest (Dillon, 2003), the habitat in which it was tested here. However, it is not known whether $S$. feltiae's natural hosts at such sites include pine weevils.

$S$. carpocapsae is reported to remain near the soil surface (Ferguson et al., 1995; Georgis and Poinar, 1983), but this is not supported by the results of the destructive stump sampling. All of the species, including S. carpocapsae, parasitized weevils at a depth of $30-39 \mathrm{~cm}$ below soil level and a distance of $40-49 \mathrm{~cm}$ from the bole. The proportion of weevils parasitized by nematodes declined with distance from the bole of the stump, where the nematodes were applied, and with depth below the soil surface, but the rate of decline (shown by the slope of the regression) was no greater for $S$. carpocapsae than for the other species. In fact, the steepest decline in parasitism with distance was for $H$. downesi, the "cruiser" and the decline in parasitism with depth was similar for all of the nematodes tested. Either the distinction between cruise and ambush foragers is overemphasized, or differences in foraging strategy are unimportant in the context of stump applications, where nematodes may be passively carried along the "routeways" supplied by the stump itself. The widely held assumption that nematodes that use an ambush-type foraging strategy will not be successful against subterranean insects (Gaugler et al., 1997; Grewal et al., 2005; Hazir et al., 2003) is not supported by the performance of $S$. carpocapsae in these trials. Based on these results, species that utilize an ambush-type foraging strategy should not automatically be precluded from use against sedentary root-feeding hosts.

In 2002, each of the commercial strains was reared in wax moth larvae and applied to stumps as well as applied in the commercial preparation. For $S$. carpocapsae and $S$. feltiae, commercially produced nematodes parasitized a lower percentage of weevils than nematodes of the same strain reared through G. mellonella, while the opposite trend was seen for $H$. megidis. Culture method can influence the efficacy of some species entomopathogenic nematodes, but whether nematodes produced in insects are more (Gaugler and Georgis, 1991) or less (Grewal et al., 1999) infective than those produced in vitro varies depending on species. As there was only one batch of each treatment in our trial, and the experiment was not repeated, we cannot draw firm conclusions regarding the quality of bioreactor-produced versus insect-produced nematodes for these three strains. However, the results underline the fact that batch quality as well as nematode species is an important factor in determining the outcome of a trial. Variation in nematode quality arising from conditions during production, transport or storage may have contributed to the variable performance from year to year of strains such as the commercially produced $S$. carpocapsae. It is unclear to what extent sub optimal condition of the nematode batch at time of application contributed to the poor performance of the UK211 strain of $H$. megidis in 2001 compared to the NL-HF85 strain used in subsequent years when UK211 was not commercially available. UK211 passed our 2001 quality control bioassay (data not shown), conducted at the time the nematodes were applied to the stumps.

A higher proportion of pine weevil larvae than of either pupae or adults were parasitized by nematodes in these trials. This difference in parasitism may be due to either 
differential susceptibility of the stages, or the decreased accessibility of pupae and callow adults within their pupal chambers. Laboratory assays have given conflicting indications as to the relative susceptibility of $H$. abietis larvae and pupae to entomopathogenic nematodes. Pye and Burman (1978) found that the larval stages were more susceptible to $S$. carpocapsae than either pupae or adults, whereas Brixey (2000) found that pupae were more susceptible than larvae. The overall higher parasitism rate of larvae in stumps may, in part, be due to their feeding activity, providing more cues, and perhaps also opportunity for invasion. Feeding may increase the susceptibility of an insect if the nematodes can penetrate through the gut wall (Grewal et al., 1993). The gut wall appears to be the main invasion route for $S$. carpocapsae in $H$. abietis larvae, following entry via both mouth and anus (Pye and Burman, 1978). However, the route of entry by other nematode species is not known for H. abietis.

The percentage of insects parasitized by $H$. downesi and $S$. carpocapsae increased between the 2 and 4 week stump assessments. It is unlikely that this was due to changes in the susceptibility of immature $\mathrm{H}$. abietis, since larvae were more likely than pupae to be parasitized. The increase in parasitism probably reflects both the time taken by the nematodes to find the insects and the time taken by the insects to die after they are invaded by nematodes. Compared to other insects, which often die within 2 days at $20^{\circ} \mathrm{C}, \mathrm{H}$. abietis larvae and pupae survive for an unusually long time after direct exposure to entomopathogenic nematodes. In laboratory assays at $20^{\circ} \mathrm{C}$, very few pine weevil larvae or pupae died within 4 days, and nematode-induced mortality continued for up to 20 days after first exposure (Dillon, 2003; and unpublished results). It is likely that insects in the stumps continued to die even after the 4 week assessment, killed by both the applied nematodes and by nematodes that developed in the weevil cadavers. When stumps were assessed after 4 weeks, newly developed IJs were beginning to emerge from some of the Steinernemakilled insects. All of the nematode species reproduced in $H$. abietis developmental stages in the field. Field-collected insects produced from 20,000 to $100,000 \mathrm{IJ}$ s/insect, with no obvious difference in yield between species (Dillon, 2003).

\section{Conclusion}

The incorporation of nematodes into an integrated pest management program, where silvicultural steps are also taken to minimize the susceptibility of conifer seedlings to $H$. abietis damage, may provide a viable alternative to the use of chemical insecticides in European forests. These trials demonstrate the superiority of heterorhabditids in parasitizing immature $\mathrm{H}$. abietis and reducing the number of adults emerging from pine stumps. However, variation between years highlights the need for repeated testing. Both Heterorhabditis downesi $\mathrm{K} 122$ and H. megidis NL-HF85 appear to be the most effective nematodes for this purpose, with the former preferred for use in Ireland where this is the only indigenous heterorhabditid. However, the "ambusher" $S$. carpocapsae showed no particular preference for infecting insects close to the surface; performed rather well in some of our trials, and is reportedly successful against pine weevil in the UK. The ability of $S$. carpocapsae to infect pine weevil pupae is particularly remarkable, since (particularly in pine stumps) $H$. abietis pupal chambers are found deep within the wood or bark and are plugged with chewed timber, though it is possible that larvae were located by the nematodes before construction of the pupal chambers. Clearly, a reputation as an ambusher should not exclude a nematode species from being tested against subterranean and cryptic targets, as it is evident that this nematode does not simply remain on the soil surface where stumps are present.

\section{Acknowledgments}

Trials were conducted under license (TA003/01) from the Pesticide Control Services of the Irish Department of Agriculture and Food. INTERREG and Coillte Teoranta provided financial assistance and technical support. We thank the staff and summer students of the Biology Department, NUIM, for their assistance with field trials and $\mathrm{E}$ nema GmbH (Germany), Koppert Biological Systems (UK and Holland) and Becker Underwood Inc. (UK) for supplying nematodes.

\section{References}

Brixey, J., 1997. The potential for biological control to reduce Hylobius abietis damage. Forestry Commission UK, Research Information Note 273

Brixey, J., 2000. The use of entomopathogenic nematodes to control the immature stages of the large pine weevil, Hylobius abietis. PhD Thesis, University of Reading, UK.

Burman, M., Pye, A.E., Nojd, N.O., 1979. Preliminary field trials of the nematode Neoaplectana carpocapsae against larvae of the large pine weevil, Hylobius abietis (Coleoptera: Curculionidae). Ann. Entomol. Fenn. 45, 88 .

Campbell, J.F., Gaugler, R., 1993. Nictation behaviour and its ecological implications in the host search strategies of entomopathogenic nematodes (Heterorhabditidae and Steinernematidae). Behaviour 126, 155-169.

Campbell, J.F., Gaugler, R.R., 1997. Inter-specific variation in entomopathogenic nematode foraging strategy: dichotomy or variation along a continuum? Fund. Appl. Nematol. 20, 393-398.

Collins, S.A., 1993. The potential of entomopathogenic nematodes to reduce damage by Hylobius abietis L. PhD Thesis, University of London, Imperial College of Science, Technology and Medicine, UK.

Dillon, A., 2003. Biological control of the large pine weevil, Hylobius abietis L., (Coleoptera: Curculionidae) using entomopathogenic nematodes. PhD Thesis, National University of Ireland Maynooth.

Ehlers, R.U., Hokkanen, H.M.T, 1996. Insect biocontrol with non-endemic entomopathogenic nematodes (Steinernema and Heterorhabditis spp.): conclusions and recommendations of a combined OECD and COST workshop on scientific and regulatory policy issues. Biocontrol Sci. Technol. 6, 295-302.

Eidmann, H.H., 1974. Hylobius Schönh. In: Schwenke, W. (Ed.), Die Forstchädlinge Europas II Käfer. Paul Parey, Berlin, pp. 275-293.

Eidt, D.C., Zervos, S., Finney-Crawley, J.R., 1995. Susceptibility of adults of Hylobius congener Dalle Torre, Shenkling, and Marshall (Coleop- 
tera: Curculionidae) to entomopathogenic nematodes. Can. Entomol. 127, 439-441.

Evans, H., Moore, R., Heritage, S., Wainhouse, D., 2004. Developments in the integrated management of the pine weevil, a pest of restocking in conifer plantations. In: Forest Research Annual Report and Accounts 2003-2004. Forestry Commission, UK, pp. 78-87.

Ferguson, C.S., Schroeder, P.C., Shields, E.J., 1995. Vertical distribution, persistence and activity of entomopathogenic nematodes (Nematoda, Heterorhabditidae and Steinernematidae) in alfalfa snout beetle (Coleoptera, Curculionidae) infested fields. Environ. Entomol. 24, 149-158.

Forst, S., Dowds, B., Boemare, N., Stackebrandt, E., 1997. Xenorhabdus and Photorhabdus spp.: bugs that kill bugs. Annu. Rev. Microbiol. 51, $47-72$.

Gaugler, R., Georgis, R., 1991. Culture method and efficacy of entomopathogenic nematodes (Rhabditida: Steinernematidae and Heterorhadbitidae). Biol. Control 1, 269-274.

Gaugler, R., Lewis, E., Stuart, R.J., 1997. Ecology in the service of biological control: the case of entomopathogenic nematodes. Oecologia 109, 483-489.

Georgis, R., Poinar jr., G.O., 1983. Effect of soil texture on the distribution and infectivity of Neoaplectana carpocapsae (Nematoda: Steinernematidae). J. Nematol. 15, 308.

Grewal, P.S., Lewis, E.E., Gaugler, R., Campbell, J.F., 1994. Host finding behaviour as a predictor of foraging strategy in entomopathogenic nematodes. Parasitology 108, 207-215.

Grewal, P.S., Converse, V., Georgis, R., 1999. Influence of production and bioassay method on infectivity of two ambush foragers (Nematoda: Steinernematidae). J. Invertebr. Pathol. 73, 40-44.

Grewal, P.S., Ehlers, R.U., Shapiro-Ilan, D.I., 2005. Nematodes as Biocontrol Agents. CABI, Wallingford, UK.

Grewal, P.S., Gaugler, R., Selvan, S., 1993. Host recognition by entomopathogenic nematodes during contact with insect gut contents. J. Parasitol. 79, 495-503.

Griffin, C.T., Moore, J.F., Downes, M.J., 1991. Occurrence of insect parasitic nematodes (Steinernematidae, Heterorhabditidae) in the Republic of Ireland. Nematologica 37, 92-100.

Hazir, S., Kaya, H.K., Stock, S.P., Keskin, N., 2003. Entomopathogenic Nematodes (Steinernematidae and Heterorhabditidae) for biological control of soil pests. Turkish J. Biol. 27, 181-202.

Hominick, W.M., 2002. Biogeography. In: Gaugler, R. (Ed.), Entomopathogenic Nematology. CABI Publishing, New York, USA, pp. 115-143.

Kenis, M., Wegensteiner, R., Griffin, C.T., 2004. Parasitoids, predators, nematodes and pathogens associated with bark weevil pests. In: Lieutier, F., Day, K.R., Battisti, A., Gregoire, J.C., Evans, H.F. (Eds.), Bark and Wood Boring Insects in Living Trees in Europe, a Synthesis. Kluwer Academic Publishers, The Netherlands, pp. 395-414.

Koppenhöfer, A.M., Kaya, H.K., 1996. Coexistence of entomopathogenic nematode species (Steinernematidae and Heterorhabditidae) with different foraging behavior. Fund. Appl. Nematol. 29, 175-183.

Langstrom, B., Day, K.R., 2004. Damage control and management of weevil pests, especially Hylobius abietis. In: Lieutier, F., Day, K.R., Battisti, A., Gregoire, J.C., Evans, H.F. (Eds.), Bark and Wood Boring Insects in Living Trees in Europe, a Synthesis. Kluwer Academic Publishers, The Netherlands, pp. $415-444$.
Leather, S.R., Day, K.R., Salisbury, A.N., 1999. The biology and ecology of the large pine weevil, Hylobius abietis (Coleoptera: Curculionidae): a problem of dispersal? Bull. Entomol. Res. 89, 3-16.

Lewis, E.E., Gaugler, R., Harrison, R., 1992. Entomopathogenic nematode host finding: response to host contact cues by cruise and ambush foragers. Parasitology 105, 103-107.

Moore, R., 2001. Emergence trap developed to capture adult large pine weevil Hylobius abietis (Coleoptera: Curculionidae) and its parasite Bracon hylobii (Hymenoptera: Braconidae). Bull. Entomol. Res. 91, 109-115.

Nordenhem, H., Nordlander, G., 1994. Olfactory oriented migration through soil by root living Hylobius abietis (L.) larvae (Col.: Curculionidae). J. Appl. Entomol. 117, 457-462.

Nordlander, G., 1987. A method for trapping Hylobius abietis (L.) larvae with standardised bait and its potential for forecasting seedling damage. Scand. J. Forest Res. 2, 199-213.

Nordlander, G., Eidmann, H.E., Jacobsson, U., Nordenhem, H., Sjodin, K., 1986. Orientation of the pine weevil Hylobius abietis to underground sources of host volatiles. Entomol. Exp. Appl. 41, 91-100.

Norlander, G., Nordenhem, H., Bylund, H., 1997. Oviposition pattern of the pine weevil, Hylobius abietis. Entomol. Exp. Appl. 85, 1-9.

Orlander, G., Nilsson, U., Norlander, G., 1997. Pine weevil abundance on clearcuttings of different ages: a 6-year study using pitfall traps. Scand. J. Forest Res. 12, 225-240.

Orlander, G., Nilsson, U., 1999. Effect of reforestation methods on pine weevil (Hylobius abietis) damage and seedling survival. Scand. J. Forest Res. 14, 341-354.

Pye, A.E., Burman, M., 1978. Neoaplectana carpocapsae: infection and reproduction in large pine weevil larvae, Hylobius abietis. Exp. Parasitol. 46, 1-11.

Pye, A.E., Pye, N.L., 1985. Different applications of the insect parasitic nematode Neoaplectana carpocapsae to control the large pine weevil, Hylobius abietis. Nematologica 31, 109-116.

Selander, J., 1993. Survival model for Pinus sylvestris seedlings at risk from Hylobius abietis. Scand. J. Forest Res. 8, 66-72.

Shapiro-Ilan, D.I., Gouge, D.H., Koppenhöfer, A.M., 2002. Factors affecting commercial success: case studies in cotton, turf and citrus. In: Gaugler, R. (Ed.), Entomopathogenic Nematology. CABI Publishing, New York, pp. 333-355.

Stock, P., Griffin, C.T., Burnell, A.M., 2002. Morphological characterisation of three isolates of Heterorhabditis Poinar, 1997 from the 'Irish group' (Nematoda: Rhabditida: Heterorhabditidae) and additional evidence supporting their recognition as a distinct species, $H$. downesi sp. Syst. Parasitol. 51, 95-106.

Ward, D., Keane, M., Seaby, D., 1993. Harmful organisms in forestry production. In: Kavanagh, J.A., Brennan, P. (Eds.), Plant Health and 1992. Royal Irish Academy, pp. 45-54.

Willoughby, I., Evans, H., Gibbs, J., Pepper, H., Gregory, S., Dewar, J., Nisbet, T., Pratt, J., McKay, H., Siddons, R., Mayle, B., Heritage, S., Ferris, R., Trout, R., 2004. Reducing pesticide use in forestry-practical guide. The Forestry Commission, pp. 25-29.

Woodring, J.L., Kaya, H.K., 1988. Steinernematid and heterorhabditid nematodes: A handbook of techniques. Arkansas Agricultural Experiment Station, Fayetteville, Arkansas, Southern Cooperative Series Bulletin 331. 